\title{
Evaluating Occurrence of Variable Cleft Lip and Palate Types Among Ethnic Groups of Malaysia
}

\author{
Syed Yousif Ali Shah ${ }^{1}$ \\ Shahid Ali Mirani \\ Muhammad Amin Sahito ${ }^{3}$
}

\author{
BDS, MDSc \\ BDS, MPhil, PhD \\ BDS, MSc
}

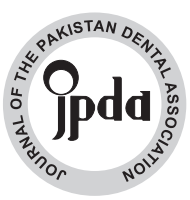

OBJECTIVE: The objective was to assess the distribution of types of cleft lip and palate (CLP) among different racial groups living in Malaysia.

METHODOLOGY: This study was carried out in two tertiary care hospitals of Malaysia, during August 2007 to March 2009. Total 526 CLP patients registered in the hospital records during the study period were included. The Modified Craniofacial Anomalies Registration (CARE) form was used to collect data of different types of oral clefts in relation to race among Malaysian.

RESULTS: Of the total 526 patients registered in the study hospital records during the study period. Majority $(86.7 \%)$ of these patients were in the age group < 18years, most $(56.7 \%)$ of them were females. The racial distribution of patients was $88.6 \%$ Malays, $8.7 \%$ Chinese, $2.5 \%$ Indian and $0.2 \%$ others. The right side oral cleft was found in $96.1 \%$ of Malay study subjects and $3.9 \%$ Chinese. Among Chinese ethnic participants, majority (52\%) had bilateral oral cleft. Overall data indicates hard palate cleft was present in 3.7\% Malay, 4.6\% Chinese, and 23\% Indian study participants. However, soft plate cleft was present in $4 \%$ Malay and 7.6\% Indian. Among ethnic groups $92 \%$ of Malay patients, $95 \%$ of Chinese and $69 \%$ of Indian had hard and soft palate cleft.

CONCLUSION: Malay ethnic group was most commonly affected racial group in this study followed by Chinese and Indian origin.

KEY WORDS: Ceft lip, cleft palate, race, ethnic, Malaysia

HOW TO CITE: Shah SYA, Mirani SA, Sahito MA. Evaluating occurrence of variable cleft lip and palate types among ethnic groups of malaysia. J Pak Dent Assoc 2018;27(1):9-12.

DOI: https://doi.org/10.25301/JPDA.271.9

Received: 23 November, 2017, Accepted: 29 December, 2017

\section{INTRODUCTION}

$\mathrm{T}$ he oral clefts is one of leading cause of increased infant mortality and poor quality of life across the globe. The oral cleft patients in developing world face greater problems due to lack of access to quality healthcare. The patients of cleft lip and palate (CLP) face significant feeding and speech problems. In addition, hearing loss and delayed midface development in CLP patients is also present. ${ }^{1}$

The occurrence of cleft lip and palate (CLP) varies significantly among various racial groups. The reported incidence of CLP is 1 in 1,000 births in whites, 1 in 500 births in Asians and Native Americans and approximately 1 in 2,400 to 2,500 births in people of African descent. ${ }^{2-4}$

1. Associate Professor, Department of Oral Medicine and Periodontology, Bibi Aseefa Dental College, SMBB Medical University Larkana.

2. Assistant Professor and Head Department of Science of Dental Materials, Bibi Aseefa Dental College, SMBB Medical University Larkana.

3. Assistant Professor, Community Dentistry, Bibi Aseefa Dental College, SMBB Medical University Larkana.

Corresponding author: "Dr. Shahid Ali Mirani”" <shahid.ali@lumhs.edu.pk>
The variable factors including heredity, nutrition, drug abuse, and environmental factors have been reported to contribute to oral clefts. ${ }^{5}$ The cleft lip and palate (CLP) is the most common oral cleft deformity followed by isolated cleft lip and isolated cleft palate. ${ }^{6}$

The variation in birth prevalence of oral clefts in different geographic locations is due to sampling type, population (hospital versus population), race and inclusion/exclusion criteria. The birthplace of babies with CLP in terms of home or hospital delivery influences registration of cases. However, CLP cases may be missed because the anomaly remains undiagnosed at the time of birth or because of lack of interest in registration. ${ }^{7}$

The complete registration of CLP cases requires pooling of data from several sources. ${ }^{8}$ The prevalence of CLP among ethnic groups across the globe vary. In population of Europe and North America extensive birth prevalence of CLP has been reported. In comparison, lower CLP birth prevalence among African-American populations have been observed. ${ }^{9}$ Malaysia is a multi-racial country of Malays, Chinese, Indians and others. To best of authors' knowledge prevalence of CLP 
among different Malaysian races at multi center level has not been carried out. Therefore, present study made an attempt to report types of oral cleft among Malaysian ethnic groups at two tertiary care hospitals. The findings of this study will help in planning treatment and counselling of CLP patients.

\section{OBJECTIVES}

To assess the distribution of types of cleft lip and palate and compare its prevalence among different races living in Malaysia.

\section{METHODOLOGY}

This study was carried out in two tertiary care hospitals of Malaysia, namely University of Malaya Medical Centre (UMMC) and Hospital Kota Bharu/ Hospital Raja Perumpuan Zainab II (HKB/ HRPZII) during August 2007 to March 2009. Permission from the administrators of the study hospitals was obtained. The cleft lip and /or palate patients who attended the study hospitals during 2003 to 2007 were included in to the study. The CLP patients who were younger than 10 years were excluded. The oral cleft patients whose record was incomplete were excluded. The data on epidemiology of CLP among different races by reviewing the record of patients who came to study hospitals for treatment from. Total 526 patients registered in the hospital records during the study period were included. Modified Craniofacial Anomalies Registration (CARE) form was used as data collection tool for study variables. This form comprised of oral cleft details. ${ }^{10}$ Data was analysed using Statistical Package for Social Sciences (SPSS version 16.). Descriptive statistical analysis was carried out to determine frequencies of types of oral clefts in study population. The Ethic Committee, University of Malaya approved the present study.

\section{RESULTS}

In present study total 526 CLP patients registered in the study hospital records were included. Majority $(86.7 \%)$ of these patients were in the age group $\leq 18$ years, most (56.7\%) of them were females. The racial distribution of patients was $88.6 \%$ Malays, $8.7 \%$ Chinese, $2.5 \%$ Indian and $0.2 \%$ others (Table. 1). Among Malay patients $77 \%$ had CLP, 12 $\%$ had CP and $9 \%$ had CL. In Chinese patients $76 \%$ of cases were of CLP, $17 \% \mathrm{CP}$ and $6.5 \% \mathrm{CL}$. Moreover, 76 $\%$ Indian had CLP as listed in Table 2. Furthermore, distribution of $\mathrm{CP}$ types among Malay, Chinese, Indian and other races is listed in Table 3. The occurrence of soft and hard palate cleft was more frequent affecting $92 \%$ Malay,
Table 1: Race Distribution $(\mathrm{n}=526)$

\begin{tabular}{|l|l|l|}
\hline Race & Frequency (n) & Percentage (\%) \\
\hline Malay & 466 & 88.6 \\
\hline Chinese & 46 & 8.7 \\
\hline Indian & 13 & 2.5 \\
\hline Others & 1 & 0.2 \\
\hline All & 526 & 100 \\
\hline
\end{tabular}

Table 2: Distribution of facial cleft type among different races

\begin{tabular}{|l|l|l|l|l|}
\hline Race & $\begin{array}{l}\text { Cleft lip (CL) } \\
\mathrm{n}(\%)\end{array}$ & $\begin{array}{l}\text { Cleft palate (CP) } \\
\mathrm{n}(\%)\end{array}$ & $\begin{array}{l}\text { Cleft lip and palate } \\
(\mathrm{CLP}) \mathrm{n}(\%)\end{array}$ & $\begin{array}{l}\text { Total } \\
\mathrm{n}(\%)\end{array}$ \\
\hline Malay & $43(9.2)$ & $60(12.87)$ & $363(77.89)$ & 466 \\
\hline Chinese & $3(6.5)$ & $8(17.3)$ & $35(76)$ & 46 \\
\hline Indian & $0(0.0)$ & $3(23)$ & $10(76.92)$ & 13 \\
\hline Others & 0 & 0 & $1(100)$ & 1 \\
\hline
\end{tabular}

Table 3: The distribution of cleft palate type according to races

\begin{tabular}{|l|l|l|l|l|}
\hline Race & $\begin{array}{l}\text { Soft palate cleft } \\
\mathrm{n}(\%)\end{array}$ & $\begin{array}{l}\text { Hard palate cleft } \\
\mathrm{n}(\%)\end{array}$ & $\begin{array}{l}\text { Soft and hard palate } \\
\text { cleft } \mathrm{n}(\%)\end{array}$ & $\begin{array}{l}\text { Total } \\
\mathrm{n}(\%)\end{array}$ \\
\hline Malay & $17(4)$ & $16(3.7)$ & $390(92.1)$ & 423 \\
\hline Chinese & $0(0.0)$ & $2(4.65)$ & $41(95.3)$ & 43 \\
\hline Indian & $1(7.69)$ & $3(23)$ & $9(69.2)$ & 13 \\
\hline Others & $0(0.0)$ & $0(0.0)$ & $1(100)$ & 1 \\
\hline
\end{tabular}

Table 4: The distribution of cleft side in relation to different races

\begin{tabular}{|l|l|l|l|l|}
\hline Race & $\begin{array}{l}\text { Right } \\
\mathrm{n}(\%)\end{array}$ & $\begin{array}{l}\text { Left } \\
\mathrm{n}(\%)\end{array}$ & $\begin{array}{l}\text { Bilateral } \\
\mathrm{n}(\%)\end{array}$ & $\begin{array}{l}\text { Total } \\
\mathrm{n}(\%)\end{array}$ \\
\hline Malay & $124(26.6)$ & $148(31.75)$ & $194(41.6)$ & 466 \\
\hline Chinese & $5 \quad(10)$ & $17(36.9)$ & $24(52.1)$ & 46 \\
\hline Indian & 0 & $6(46)$ & $7(53.8)$ & 13 \\
\hline Others & 0 & 1 & 0 & 1 \\
\hline
\end{tabular}

$95 \%$ Chinese and $69 \%$ Indian study subjects. Furthermore, details about pattern of oral cleft side among study races is elucidated in Table 4. The bilateral oral cleft was found among $53.8 \%$ Indians, 52.1\% Chinese and $41.6 \%$ Malay subjects.

\section{DISCUSSION}

Orofacial clefts significantly lead to long-term financial and psychological stress for affected subjects and their families. The surgical treatment for orofacial cleft involves multidisciplinary approach. The treatment begins shortly after birth and may continue up to teenage and comprise of multiple surgeries and long-term speech therapy combined with orthodontic treatment. ${ }^{11}$

The present study found that out of 526 CLP patients, the racial distribution of patients was $88.6 \%$ Malays, $8.7 \%$ Chinese, $2.5 \%$ Indian and $0.2 \%$ others. Among Malay 
patients $77 \%$ had CLP, $12 \%$ had CP and $9 \%$ had CL. In Chinese patients $76 \%$ of cases were of CLP, $17 \% \mathrm{CP}$ and $6.5 \%$ CL. Moreover, $76 \%$ Indian had CLP. The results of present study are in agreement with findings previous studies who reported that CLP was most frequent type of oral cleft in Malaysian population. ${ }^{12,13}$ However, to best of authors' knowledge no study was found in literature stating racial distribution of oral clefts in Malaysia. Moreover, these results of current study are consistent with several other epidemiologic studies. ${ }^{14-16}$ Furthermore, many other published studies report higher percentage of CLP compared to isolated CL and CP. The percentage of CLP was $66 \%$ in Brazil, $78.3 \%$ in Saudi Arabia, $76.8 \%$ in Sudan and in Mexico it was found to be $70 \% \cdot{ }^{17-20}$

The occurrence of soft and hard palate was more frequent affecting $92 \%$ Malay, $95 \%$ Chinese and $69 \%$ Indian study subjects. The bilateral oral cleft was found among $53.8 \%$ Indians, 52.1\% Chinese and $41.6 \%$ Malay subjects. In contrast to present study, unilateral cleft on left side was reported to be more predominant. ${ }^{21-23}$ Moreover, Aljohar et. al also reported occurrence of oral cleft on left-side more frequently, which is in agreement with a study conducted in China. ${ }^{24,25}$ In literature no any substantial justification for the frequent occurrence of left side cleft is found. However, it has been proposed that close proximity of blood vessels resulting in profuse blood supply to right side of the fetal head may be one reason for less occurrence of cleft on right side. ${ }^{26,27}$ It is recommended that molecular and genetic studies of Malaysian ethnic groups with oral clefts should be carried out to explore reasons for variations in prevalence of oral clefts among ethnic groups of Malaysia.

\section{CONCLUSION}

The right side oral cleft was found in $96.1 \%$ of Malay study subjects and $3.9 \%$ Chinese. Among Chinese ethnic participants, majority ( $52 \%$ ) had bilateral oral cleft. Overall data indicates hard palate cleft was present in $3.7 \%$ Malay, 4.6\% Chinese, and 23\% Indian study participants. However, soft plate cleft was present in $4 \%$ Malay and $7.6 \%$ Indian. Among ethnic groups $92 \%$ of Malay patients, $95 \%$ of Chinese and $69 \%$ of Indian had hard and soft palate cleft.

\section{CONFLICT OF INTEREST}

None declard

\section{REFERENCES}

1. Conway JC, Taub PJ, Kling R, Oberoi K, Doucette J and Jabs EW, Ten-year experience of more than 35,000 orofacial clefts in Africa, BMC Paediatrics, 2015;15:8. https://doi.org/10.1186/s12887-015-0328-5

2. Kirschner RE and Rossa, DL. Cleft lip and palate. Otolaryngol Clin North Am; 2000; 36 (6): 1191-1215. https://doi.org/10.1016/S0030-6665(05)70277-2

3. Strong EB, Buckmiller LM. Management of the cleft palate. Facial Plast Surg Clin North Am; 2001; 9(1): 15-25. 4. Stanier P, Moore GE. Genetics of cleft lip and palate: syndromic genes contribute to the incidence of non-syndromic clefts. Hum Mol Genet; 2004; 1: 73-81.

\section{https://doi.org/10.1093/hmg/ddh05}

5. World Health Organization, Global strategy to reduce the health-care burden of craniofacial anomalies. (Available on request from the Human Genetics Programme of the World Health Organization, 2002; 1211 Geneva 27, Switzerland.) 6. Onyango JF, Noah S. Pattern of clefts of the lip and palate managed over a three-year period at a Nairobi hospital in Kenya. East Afr Med J, 2005; 82:649-651.

7. Kozelj V, Vegnuti M. Time series analysis of births of children with orofacial clefts J Craniomaxillofac Surg, 2000; 28: 201-203.

https://doi.org/10.1054/jcms.2000.0150

8. Christensen K, Fogh-Andersen P, Etiological subgroups in non-syndromic isolated cleft palate. A genetic epidemiological study of 52 Danish birth cohorts. Clin Genet. 1994; 46(5):329-35.

https://doi.org/10.1111/j.1399-0004.1994.tb04173.x

9. Khoury MJ, Weinstein A, Panny S, Holtzman NA, Lindsay PK, Farrel K, Eisenberg M Maternal cigarette smoking and oral clefts: a population-based study. Am J Pub Health, 1987;77:623-625.

https://doi.org/10.2105/AJPH.77.5.623

10. Hammond $\mathrm{M}$ and Stassen L. Do you CARE? A national register for cleft lip and palate patients. Br J Plast Surg; 1999; 52 (1): 12-17.

https://doi.org/10.1054/bjps.1998.3021

11. Anderson S L, Adams G, Plaut VC, The cultural grounding of personal relationship: the importance of attractiveness in everyday life. J Person and Soc Psycho 2008;95:352 - 368. https://doi.org/10.1037/0022-3514.95.2.352

12. Chai SC, Jimeno ZKL, Sasidaran R, Sergius A. Pilot epidemiological study of cleft lip and/or palate in Kota Kinabalu Sabah, Asian J of Medic Sci, 2013,4;86-91. 13. Tan KB, Tan KH, Yeo GS. Cleft deformities in Singapore: a population-based series 1993-2002. Singapore Med J; 2008; 49(9): 710-714.

14. Omo-Aghoja VW, Omo-Aghoja LO, et al. Antenatal determinants of oro-facial clefts in Southern Nigeria 2010 Mar;10(1):31-9.

15. Elahi MM, Jackson IT, et al. Epidemiology of cleft lip and palate in Pakistan. Plast. Reconstr. Surg 
2004;113(6):1548-1555.

https://doi.org/10.1097/01.PRS.0000117184.77459.2B

16. Yoshikazu Nagase, Nagato Natsume, et al.

Epidemiological analysis of cleft lip and/or palate by cleft pattern. J. Maxillofac. Oral. Surg, 2010; 9(4):389-395. https://doi.org/10.1007/s12663-010-0132-6

17. Barbosa D, Reis, Hercílio MJ, Letícia V, Portz Paulo R, Ferreti Bonan A. Prevalence of nonsyndromic oral clefts in a reference hospital in the state of Minas Gerais, Brazil, between 2000-2005. Braz Oral Res; 2007; 21 (4): 314-317. https://doi.org/10.1590/S1806-83242007000400006

18. Al-Balkhi KM. The distribution and classification of clefts in patients attending a cleft lip and palate clinic in Riyadh, Saudi Arabia. Saudi Med J; 2008; 29 (5): 739-742. 19. Suleiman AM, Hamzah ST, Abusalab MA and Samaan KT. Prevalence of cleft lip and palate in a hospital-based population in the Sudan. Int J Paediatr Dent; 2005;15(3):185189.

https://doi.org/10.1111/j.1365-263X.2005.00626.x 20. Blanca S, González M, L López M, A Rico, Fernando G. Oral clefts: a retrospective study of prevalence and predisposal factors in the state of Mexico. J of oral sci; 2008; 50 (2): 123 -129. https://doi.org/10.2334/josnusd.50.123
21. Feliciona Blanco-Davila. Incidence of cleft lip and palate in Northeast of Mexico: A 10 years study. The J Craniofac Surg 2003;14(4):533-537. https://doi.org/10.1097/00001665-200307000-00027

22. Chuangsuwanich A, Aojanepong C, Muangsombut S, and Tongpiew P. Epidemiology of cleft lip and palate in Thailand. Ann Plast. Surg.1998;10:7.12.

23. Ogle, O.E. Incidence of cleft lip and palate in a newborn Zairian sample. Cleft palate Craniofac J. 1993;30:250.

24. Srivastava S., and Bang, R.L. Facial clefting in Kuwait and England: A comparative study. Br. J. Plast. Surg. 1990;43:457.

https://doi.org/10.1016/0007-1226(90)90013-P

25. Aljohar A, Ravichandran K, Subhani S, Pattern of Cleft Lip and Palate in Hospital-Based Population in Saudi Arabia: Retrospective Study, Cleft Palate-Craniofacial J, 2008, 45; 6:592-6.

https://doi.org/10.1597/06-246.1

26. Zhou QJ, Shi B, Shi ZD, Zheng Q, Wang Y. Survey of the patients with cleft lip and palate in China who were funded for surgery by the Smile Train program from 2000 to 2002. Chin Med J. 2006; 119:1695-1700.

27. Johnston C, Brown KS. Human population data. General discussion III. Prog Clin Biol Res 1980; 46.117131. 